\title{
DURATION OF TELL SETTLEMENTS AT FOUR PREHISTORIC SITES IN HUNGARY
}

\author{
EDE HERTELENDI, ${ }^{1}$ EVA SVINGOR, ${ }^{1}$ PÁL RACZKY,${ }^{2}$ FERENC HORVÁTH,${ }^{3}$ ISTVÁN FUTO $^{1}$ \\ and LÁSZLÓ BARTOSIEWICZ ${ }^{2}$
}

\begin{abstract}
The chief objective of this paper is to improve our understanding of the Neolithic in eastern Hungary using absolute chronological data. To accomplish this we calibrated new measurements as well as previously published dates. The up-to-date, standardized evaluation of 147 calibrated measurements showed temporal overlaps between archaeological cultures defined on the basis of ceramic styles. The average timespan of tell settlements of $285 \mathrm{yr}$ was obtained using radiocarbon dates from four major settlements in eastern Hungary: Berettyoújfalu-Herpály, Hódmezóvásáhely-Gorzsa-Cukortanya, Öcsöd-Kováshalom and Polgár-Csớszhalom.
\end{abstract}

\section{INTRODUCTION}

The Great Hungarian Plain is not only the westernmost edge of the Eurasian steppe belt, but it also marks the edge of the northwestern distribution of prehistoric tell sites in Europe (Bognár-Kutzián 1985; Petrasch 1991). This type of settlement is characterized by consecutive layers of habitation built on top of one another to form vertical stratigraphies (Kalicz 1985; Kalicz and Raczky 1987; Horváth 1991). The diachronic interpretation of these stratified "cultures", defined mostly on the basis of ceramic styles (relative i.e., typochronological method), has intensified and has been supported by radiocarbon dates (Bognár-Kutzián and Csongor 1987; Hertelendi and Horváth 1992; Raczky 1995; Hertelendi et al. 1995). Little is known, however, about the length of occupation, the "life spans" of individual tell settlements and their precise chronological relationships with each other. Understanding the chronological relationships within groups of settlements will ultimately permit a better understanding of settlement distributions and wider social organizations of the populations that inhabited this region of Hungary. Information on life spans of individual settlements can potentially also shed light on patterns of land use at the end of the Neolithic period.

\section{Problem}

This paper is aimed at defining the time intervals within which four major tell sites in the Great Hungarian Plain may have been inhabited. Traditionally, relative chronologies are based on the diachronic stylistic/typological evaluation of both archaeological artifacts and architectural features. The economic and ethnohistoric interpretation of such data is, however, meaningless without the estimation of absolute time periods that characterized various phases of occupation. Rather than studying absolute ${ }^{14} \mathrm{C}$ dates directly in a "true" chronological order, in this study, the validity of an a priori grouping of archaeological units (strata within the studied settlements) is tested using corresponding ${ }^{14} \mathrm{C}$ dates. Thus, the earliest and latest dates for stylistically defined cultures can be determined in absolute terms, which is also of help in appraising their contemporaneity at different sites. Thus, the intra-site life spans of cultures may also be compared on a regional basis. In a sense, this means that each stratum within sites may be treated as a separate village that existed and perhaps interacted with other villages, also represented by strata within a particular site. Slowly, a picture begins to emerge of settlement distributions at any given time. In this way, larger-scale changes in settlement organization within the region may also be monitored.

\footnotetext{
${ }^{1}$ Institute of Nuclear Research of the Hungarian Academy of Sciences, POB 51, H-4001 Debrecen, Hungary

${ }^{2}$ Institute of Archaeological Sciences, Loránd Eötvös University, POB 107, H-1364 Budapest, Hungary

${ }^{3}$ Ferenc Móra Museum, Roosevelt tér 1-3, H-6701 Szeged, Hungary
} 


\section{MATERIAL AND METHODS}

Systematic ${ }^{14} \mathrm{C}$ dating of four major settlements has been carried out since 1989: 1) Öcsöd-Kováshalom (14 samples); 2) Hódmezóvásárhely-Gorzsa-Cukortanya (20 samples); 3) Polgár-Csószhalom (76 samples); and 4) Berettyoújfalu-Herpály (37 samples). The stratified tell Polgár-Csószhalom is also associated with a single-layer, horizontal settlement, Polgár 6 (27 samples), whose dates are discussed in this study. Within the latter settlement it may also be possible to prove or disprove contemporaneity between various parts of the ancient village. Figure 1 shows the sites' locations.

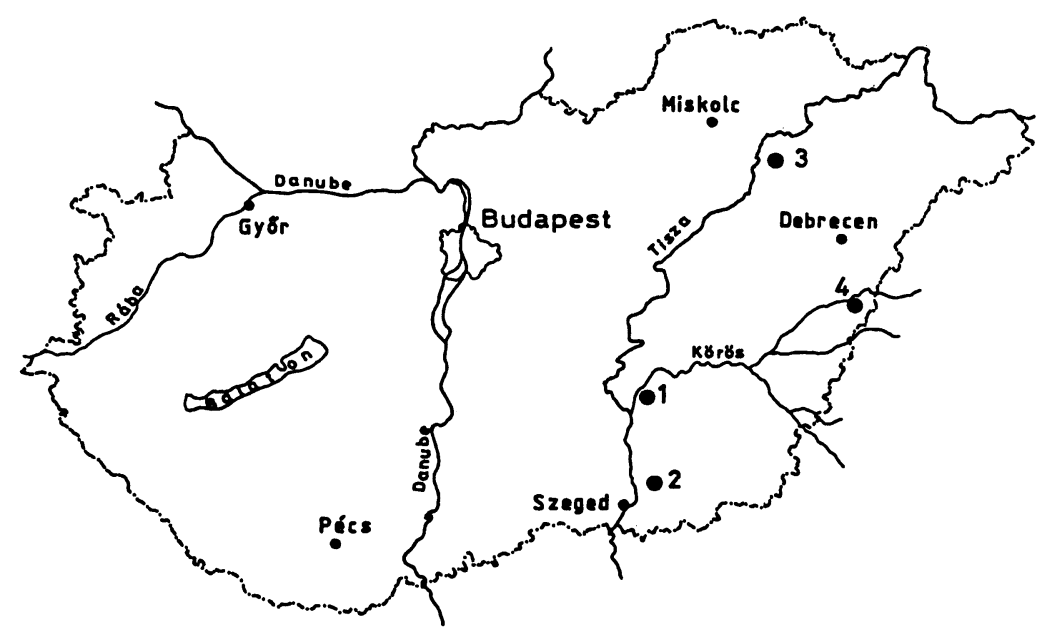

Fig. 1. Geographical distribution of sites. 1. Öcsöd-Kováshalom; 2. HódmezóvásárhelyGorzsa-Cukortanya; 3. Polgár-Csószhalom; 4. Berettyoújfalu-Herpály.

Archaeologically, the sites under discussion here represent different relative chronological intervals. Berettyóújfalu-Herpály (5 typochronological levels) and Hódmezớvásárhely-Gorzsa-Cukortanya (4 typochronological levels) represent the most complete relative chronological, "cultural" continuum, from the beginning of the Late Neolithic Period to the Copper Age. As is shown by the stylistic distribution of ceramic materials, the tell site of Polgár Csószhalom can be subdivided into two main (early and later) phases within the same interval. The horizontal settlement adjacent to this tell seems to be related to the earlier Late Neolithic strata. Occupation at the shorter-lived, and apparently early Late Neolithic tell of Öcsöd-Kováshalom ( 2 levels) also ceased before the end of the Neolithic Period in the Great Hungarian Plain.

To determine the probability distribution of more than one BP date, we first calibrated each one (van der Plicht and Mook 1989), which yielded a real calendar age distribution $y(x)$. Results were then normalized so that the area $\int y(x) d x=1$. Only then were the individual real age distributions $y(x)$ added. Of the total summed function $y_{\text {tot }}(x)$, the probability distribution $P(x)$ was obtained, again normalized to a total probability of 1 (or $100 \%$ ). We did not pretreat the ${ }^{14} \mathrm{C}$ ages in any way, as outlined by Aitchison et al. (1991). The calibrated probability distributions along the calendar $(x)$ axis were analyzed as shown in Figure 2 (Berettyóujfalu-Herpály data). The dashed area under the probability distribution curve is $68.3 \%$ of the total area. The intercepts of the bordering lines of this area with the calendar $(x)$ axis can be taken as the calibrated ranges. This analysis follows the procedure of Stuiver and Reimer (1987). To calculate the calibrated BC age ranges from sum of probability distribution we used the program Calib Rev. 3.0.3 (Stuiver and Reimer 1993; Stuiver and Pearson 1993). 


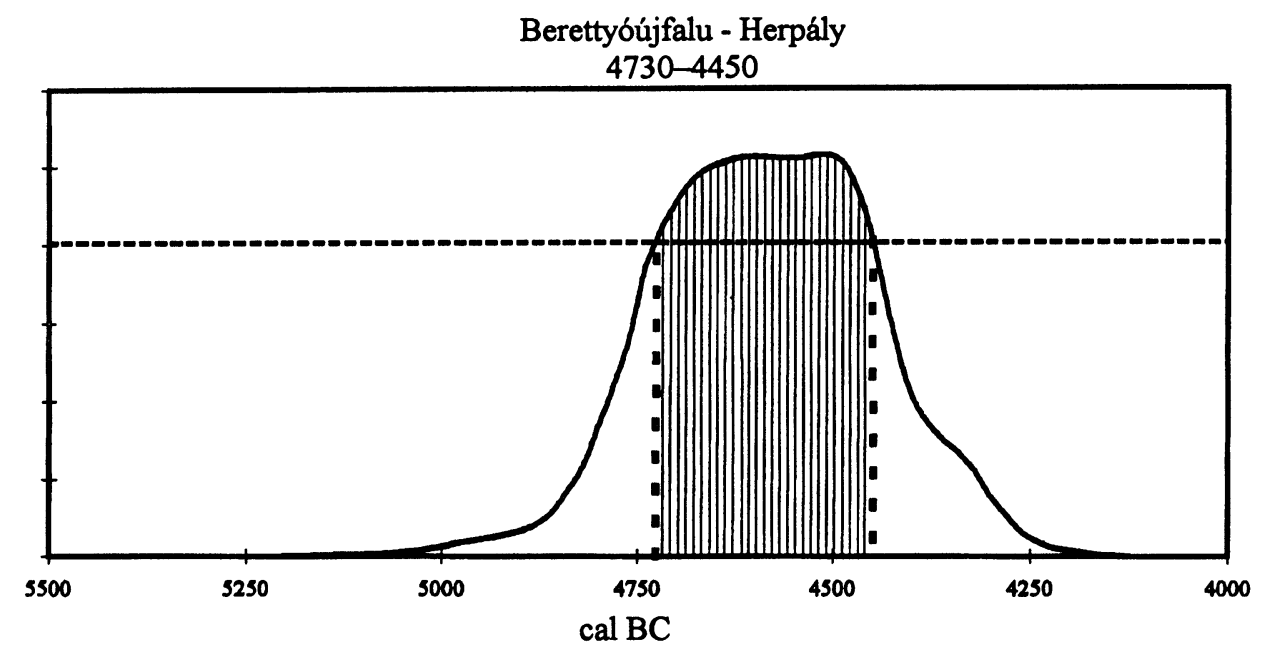

Fig. 2. Calculation of the $68.3 \%$ confidence level of the summed probability function of the BerettyoújfaluHerpály data

TABLE 1. Summarized ${ }^{14} \mathrm{C}$ Dates of the Strata at the Four Tell Sites Studied

\begin{tabular}{lccc} 
& $\begin{array}{c}\text { No. of } \\
\text { Tell settlement }\end{array}$ & $\begin{array}{c}\text { Confidence interval } \\
(68.3 \%)\end{array}$ & $\begin{array}{c}\text { Time span } \\
(68.6 \%)\end{array}$ \\
\hline Öcsöd-Kováshalom & 14 & $5110-4830$ & 280 \\
Level 1 & 7 & $5181-4931$ & 250 \\
Level 2 & 7 & $5020-4782$ & 238 \\
Hódmezôvásárhely-Gorzsa-Cukortanya & 20 & $4850-4550$ & 300 \\
Polgár Csö́szhalom & 76 & $4840-4560$ & 280 \\
Level 3 & 16 & $4905-4646$ & 259 \\
Level 2 & 6 & $4843-4692$ & 151 \\
Level 1 & 54 & $4795-4530$ & 265 \\
Berettyoújfalu-Herpály & 37 & $4730-4450$ & 280 \\
Level 9 & 3 & $4822-4560$ & 262 \\
Level 8 & 14 & $4749-4495$ & 254 \\
Level 7 & 10 & $4747-4371$ & 376 \\
Level 6 & 5 & $4644-4428$ & 216 \\
Level 5 & 5 & $4601-4386$ & 215 \\
\hline
\end{tabular}

\section{RESUlTS}

We divided the Late Neolithic tells from eastern Hungary into ten stratigraphic groups. ${ }^{14} \mathrm{C}$ dates available for this study were classified within their respective groups in Table 1 (see also Fig. 4). Using calibrated ${ }^{14} \mathrm{C}$ dates from the Great Hungarian Plain, we constructed a series of cumulative probability densitograms (Fig. 3). These show the absolute chronological boundaries and duration of the ten cultural groups for which sufficiently great numbers of samples were available. 

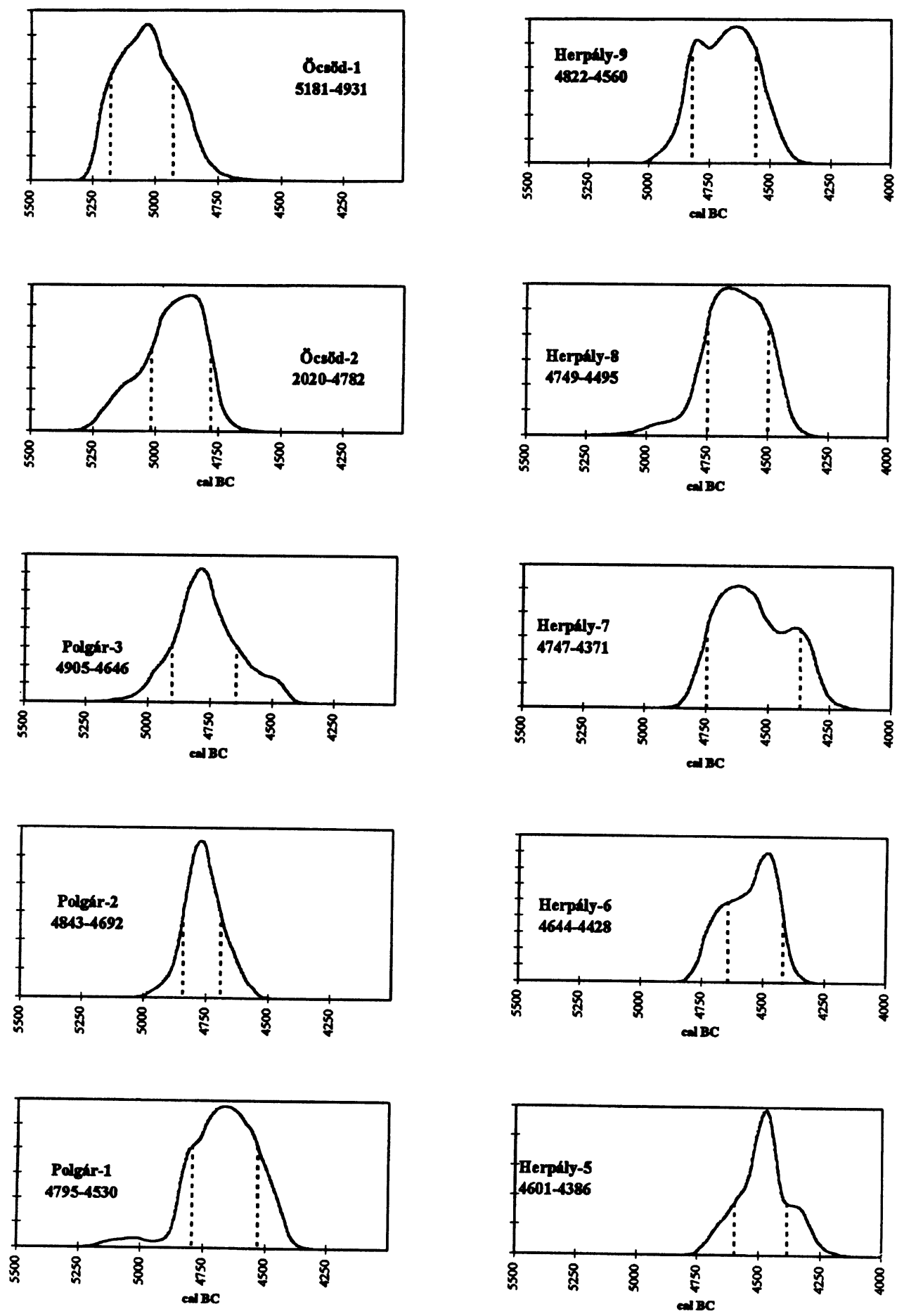

Fig. 3. Smoothed cumulative probability density functions of the typochronological levels of tell settlements 



Fig. 4. The life spans of the four major tell settlements in eastern Hungary 


\section{Conclusion}

These results shed new light on the following archaeological phenomena:

1. ${ }^{14} \mathrm{C}$ dates from four Late Neolithic sites on the Great Hungarian Plain show that, on average, tell stratigraphies represent a 285 -yr time interval (Fig. 4). This result, however, represents only the minimum possible real time of occupation, since in the cases of HódmezóvásárhelyGorzsa, Polgár-Csószhhalom and Berettyóújfalu-Herpály, only sporadic data are available from the earliest strata. Meanwhile, the life spans of these three tells fall between 4850 and $4450 \mathrm{BC}$, which reconfirms archaeological arguments concerning their contemporaneity, and the hypothesis that together they cover some $400 \mathrm{yr}$ of the Late Neolithic.

2. On the basis of archaeological evidence, Öcsöd-Kováshalom was dated to the very beginning of the Late Neolithic and as such has been regarded as one of the earliest tells on the Great Hungarian Plain. This research hypothesis is convincingly supported by the $5110-4830 \mathrm{BC}$ interval into which ${ }^{14} \mathrm{C}$ dates from the site fall. Moreover, there is only a small temporal overlap between the end of occupation at this site and the beginnings of settlement at the three aforementioned tells. Archaeological observations are suggestive of somewhat more parallelism between Öcsöd and the other three sites, whose poor show in terms of absolute dates may be due to the aforementioned underrepresentation of the earliest strata of Gorzsa, Csőszhalom and Herpály within the ${ }^{14} \mathrm{C}$ samples.

3. Presuming that these four sites on the Great Hungarian Plain cover the entire timespan of Late Neolithic development in the region of the Tisza River, the earliest date from Öcsöd-Kováshalom and the latest date from Berettyóújfalu-Herpály delineate a time range between 5110 and $4450 \mathrm{BC}$ for this archaeological period. This corresponds to $660 \mathrm{yr}$ of Late Neolithic occupation, more than twice the length of the mere $300 \mathrm{yr}$ postulated on a purely typochronological basis (Makkay 1982). This phenomenon falls in line with the general tendency that ${ }^{14} \mathrm{C}$ dating radically expands the time intervals estimated for prehistoric (especially Neolithic and Copper Age) cultures. The longer life span of the Late Neolithic outlined in this study, however, is additionally supported by a convincing match between the $4450 \mathrm{BC}$ latest absolute date and the widely accepted $4500 / 4400 \mathrm{BC}$ date that marks the beginning of the Copper Age.

4. Dates obtained for the Tisza-Herpály-Csószhalom complex also fall in line with the most recent results obtained by Ruoff and Gross (1991) as well as the conclusions drawn by Gläser (1996) and Schier (1996). Although the latter authors studied the Vinča culture, their analyses are fully relevant to the absolute chronology of the Late Neolithic in the Great Hungarian Plain. Of the relative chronological questions they discuss, it is especially important that the beginnings of the Tisza culture may be considered parallel with the Vinca B1 and B2 phases, not only on the basis of stylistic similarities, but in terms of ${ }^{14} \mathrm{C}$ dates as well.

5. Comparisons between the ${ }^{14} \mathrm{C}$ dates and stratigraphies of the four tell sites from the Great Hungarian Plain show that, at the present level, the use of ${ }^{14} \mathrm{C}$ measurements has proved to be very limited in fine-tuning stratigraphic and typochronological phases. The error margins of these measurements pose a natural obstacle, which does not make 15-20-yr distinctions between construction phases possible, as would be the case with dendrochronology, for example, in the lakeshore pile dwellings of the Alpine Foreland (Schlichterle 1989).

\section{ACKNOWLEDGMENTS}

This work was supported by the National Science Foundation of Hungary (OTKA grant no. T 18179). We gratefully acknowledge the technical assistance provided by Ms. Magdolna Mogyorósi. 


\section{REFERENCES}

Aitchison, T. C., Ottaway, B. S. and Al-Ruzaiza, A. S. 1991 Summarizing a group of ${ }^{14} \mathrm{C}$ dates on the historical time scale: With a worked example from the Late Neolithic of Bavaria. Antiquity 65: 108-116.

Bognár-Kutzián, I. 1985 Contribution to the prehistoric chronology of Hungary. Mitteilungen des Archäologischen Institutes der Ungrarischen. Akademie der Wissenschaften 14: 293-298.

Bognár-Kutzián, I. and Csongor, É. 1987 New results of radiocarbon dating of archaeological finds in Hungary. In Pécsi, M. and Csongor, E., eds., The Holocene Environment in Hungary. Budapest, Akadémiai Kiad6: 131-140.

Gläser, R. 1996 Zur absoluten Datierung der Vinča-Kultur anhand von ${ }^{14} \mathrm{C}$ Daten. In Drasovean, F., ed., The Vinca culture, its role and cultural connections. International Symposium, Timisoara. Bibliotheca Historica et Archaeologica Banatica II: 175-12.

Hertelendi, E. and Horváth, F. 1992 Radiocarbon chronology of late Neolithic settlements in the Tisza-Maros region, Hungary. In Long, A. and Kra R. S., eds., Proceedings of the 14th International ${ }^{14} \mathrm{C}$ Conference. Radiocarbon 34(3): 859-866.

Hertelendi, E., Kalicz, N., Raczky, P., Horváth, F., Veres, M., Svingor, E., Futó, I. and Bartosiewicz, L. 1995 Reevaluation of the Neolithic in eastern Hungary based on calibrated radiocarbon dates. In Cook, G. T., Harkness, D. D., Miller, B. F. and Scott, E. M., eds., Proceedings of the 15 th International ${ }^{14} \mathrm{C}$ Conference. $\mathrm{Ra}$ diocarbon 37(2): 239-245.

Horváth, F. 1991 Vinca culture and its connections with the southeast Hungarian Neolithic: A comparison of traditional and ${ }^{14} \mathrm{C}$ chronology. Banatica 11: 259-273.

Kalicz, N. 1985 On the chronological problems of the Neolithic and Copper Age in Hungary. Mitteilungen des Archäologischen Institutes der Ungarischen Akademie der Wissenschaften 14: 21-51.

Kalicz, N. and Raczky, P. 1987 The Late Neolithic of the Tisza region. A survey of recent archaeological research. In Raczky, P., ed., The Late Neolithic of the Tisza region. Budapest, Szolnok: 11-30.

Makkay, J. 1982 A magyarországi neolitikum ku- tatásanak új eredményei. Az idórend és a népi azonositás kérdései (New results in the research of the Hungarian Neolithic. Questions of chronology and ethnic identification). Budapest, Akadémiai Kiadó.

Petrasch, J. 1991 Zur absoluten Chronologie des südostund mitteleuropäischen Neolithikums. Banatica 11: 65-71.

Raczky, P. 1995 New data on the absolute chronology of the Copper Age in the Carpathian Basin. In Kovács, T., ed., Neuere Daten zur Siedlungsgeschichte und Chronologie der Kupferzeit des Karpatenbeckens. IPH: 51-59.

Ruoff, M. and Gross, E. 1991 Die Bedeutung der absoluten Datierung der jungsteinzeitlichen Kulturen in der Schweiz für die Urgeschichte Europas. In Lichardus, J., ed., Die Kupferzeit als historische Epoche. Symposium Saarbrücken und Otzenhausen: 401-420.

Schier, W. 1996 The relative and absolute chronology of Vinca: New evidence from the type site. In Drasovean, F., ed., The Vinča culture, its role and cultural connections. International Symposium. Timisoara, Bibliotheca Historica et Archaeologica Banatica II: 141-162.

Schlichterle, H. 1989 Pfahlbauten: Die frühe Besiedlung des Alpenvorlandes. Spektrum der Wissenschaft Juni: 72-85.

Stuiver, M. and Pearson, G. W. 1993 High-precision bidecadal calibration of the radiocarbon time scale, $\mathrm{AD}$ 1950-500 BC and 2500-6000 BC. In Stuiver, M., Long, A. and Kra, R. S., eds., Calibration 1993. Radiocarbon 35(1): 1-23.

Stuiver, M. and Reimer, P. J. 1987 User's guide to the program Calib and Display Rev 2.1: Quaternary Isotope Laboratory, University Washington, Seattle.

1993 Extended ${ }^{14} \mathrm{C}$ data base and revised CALIB $3.0{ }^{14} \mathrm{C}$ age calibration program. In Stuiver, M., Long, A. and Kra, R. S., eds., Calibration 1993. Radiocarbon 35(1): 215-231.

van der Plicht, J. and Mook, W. G. 1989 Calibration of ${ }^{14} \mathrm{C}$ data by computer. In Long, A., Kra, R. S. and Srdoc, D., eds., Proceedings of the 13th International ${ }^{14} \mathrm{C}$ Conference. Radiocarbon 31(3): 805-816. 